Wulan Sari Fadilla, Syamsir I Pengaruh Umur dan Status Perkawinan terhadap Kinerja Perangkat Nagari dalam Pengelolaan Keuangan Nagari di Kabupaten Tanah Datar

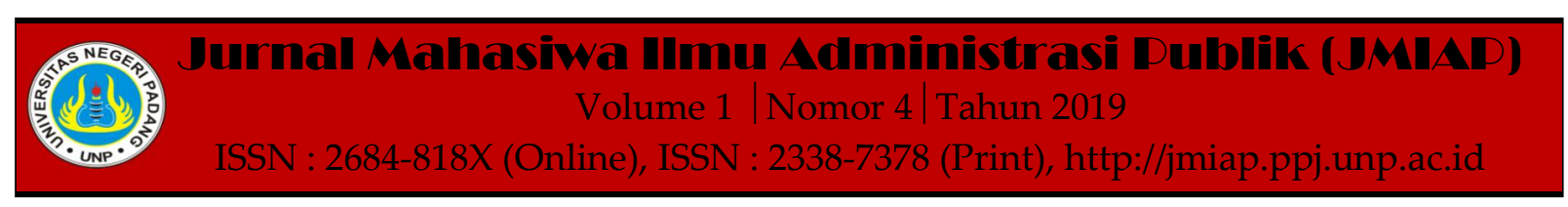

\title{
PENGARUH UMUR DAN STATUS PERKAWINAN TERHADAP KINERJA PERANGKAT NAGARI DALAM PENGELOLAAN KEUANGAN NAGARI DI KABUPATEN TANAH DATAR
}

\author{
Wulan Sari Fadilla ${ }^{1(a)}$, Syamsir $^{2(b)}$ \\ ${ }^{1}$ Jurusan Ilmu Administrasi Negara, Universitas Negeri Padang \\ ${ }^{2}$ Jurusan Ilmu Administrasi Negara, Universitas Negeri Padang \\ a)ws1468756@gmail.com, ${ }^{b}$ syamsirsaili@yahoo.com
}

\begin{abstract}
This study aimed to determine the effect of age and marital status on the performance of the village government apparatus in the village financial management in Tanah Datar District.The background of this study was that there were still a number of problems in village financial management that were influenced by factors of age and marital status. This research is a quantitative study with a population of 600 village government apparatus,. The sample of this study consisted of 248 determined by the Slovin formula, as well as the research sampling technique using the stage random sampling technique. Data in this study were collected through questionnaires. Data analysis in this study used descriptive analysis methods, $t$ test, and ANOVA test. The results of this study indicate that there was no influence of age and marital status on the performance of the village government apparatus in the village financial management in Tanah Datar District.
\end{abstract}

Keywords : Age, Marital Status, Performance, Nagari Financial Management

Corresponding author. Email.ws1468756@gmail.com,syamsirsaili@yahoo.com

How to cite this article. Fadilla, W. Sari \& Syamsir. (2019). Pengaruh Umur dan Status Perkawinan terhadap Kinerja Perangkat Nagari dalam Pengelolaan Keuangan Nagari di Kabupaten Tanah Datar. Jurnal Mahasiwa Ilmu Administrasi Publik (JMIAP) Jurusan Ilmu Administrasi Negara Fakultas Ilmu Sosial Universitas Negeri Padang, Volume 1 (4), Hal. 98-109.

http://jmiap.ppj.unp.ac.id

ISSN : 2684-818X (Online), ISSN : 2338-7378 (Print)

Copyright $\bigcirc 2019$. Published by Pusat Kajian-Pemberdayaan dan Pelayanan Masyarakat (PK-P2M) FIS UNP Padang 


\section{PENDAHULUAN}

Menurut Undang undang nomor 6 tahun 2014 tentang Desa adalah desa memiliki hak asal usul dan hak tradisional dalam mengatur dan mengurus kepentingan masyarakat setempat dan berperan mewujudkan cita-cita kemerdekaan berdasarkan Undang-Undang Dasar Negara Republik Indonesia Tahun 1945. Dalam perjalanan ketatanegaraan Republik Indonesia, Desa telah berkembang dalam berbagai bentuk sehingga perlu dilindungi dan diberdayakan agar menjadi kuat, maju, mandiri, dan demokratis sehingga dapat menciptakan landasan yang kuat dalam melaksanakan pemerintahan dan pembangunan menuju masyarakat yang adil, makmur, dan sejahtera.Kebijakan mengenai pelaksanaan keuangan desa diatur dalam peraturan Menteri Dalam Negeri Nomor 113 Tahun 2014 Tentang Pengelolaan Keuangan Desa dan Peraturan Mentri Dalam Negeri Nomor 114 Tahun 2014 Tentang Pedoman Pembangunan Desa, bahwa:'Keuangan desa meruakan semua hak dan kewajiban desa yang dapat dinilai dengan uang, serta segala sesuatu baik berupa uang atau barang yang dapat dijadikan milik desa yang berhubungan dengan pelaksanaan hak dan kewajiban Desa.Begitupun dengan nagari di Sumatera Barat, dimana Nagari juga mendapatkan kucuran nagari dari pemerintah pusat dengan besaran yang ditetapkan masing masing kepada nagari tersebut. Adanya kebijakan pengelolaan dana nagari tersebut didukung dengan peraturan peraturan daerah yang mengatur tentang pengelolaan dana nagari tersebut.

Berdasarkan peraturan Bupati Tanah Datar Nomor 7 Tahun 2016 tentang Perubahan Atas Peraturan Bupati Nomor 11 Tahun 2015 tentang Pedoman Pengelolaan Keuangan Nagari, Peraturan ini memuat tentang bagaimana pengelolaan keuangan nagari di Kabupaten Tanah Datar. Peraturan juga mengatur mengenai asas tentang pengelolaan keuangan nagari yang transpran, akuntable, partisipatif dan dilakukan dengan disiplin anggaran dan tertib. Di Provinsi Sumatera Barat sendiri dalam lima tahun terakhir, tercatat ada tiga puluh delapan Wali Nagari yang tersandung kasus korupsi karena ketidaktahuan mereka tentang pengelolahan keuangan (BPKP:2017). Seperti halnya di Kabupaten Tanah Datar masih ditemukan permasalahan yang terkait dengan pengelolaan keuangan nagari, diantaranya adalah terdapat 3 nagari dari 75 nagari di Kabupaten Tanah Datar yang tidak dapat mencairkan Anggaran Dana Desa (ADD) Tahap I. Sehingga mengakibatkan 72 nagari lainnya terkendala dalam pecairan Anggaran Dana Desa Tahap II (dua) yang bersumber dari (APBN) Anggaran Pendapatan dan Belanja Negara. Tiga nagari yang terkendala pencairan tersebut adalah Sumaniak Kecamatan Salimpaung, Nagari Koto Baru Kecamatan X Koto, dan nagari Minangkabau Kecamatan Sungayang. (RedaksiSumbar.com).

Masalah lainnya yaiutu Kasus penggelapan dana nagari yang dilakukan oleh Walinagari Sungayang. Dana nagari ini diberikan oleh Provinsi Sumatera Barat sebagai hadiah karena anagari sungayang dinobatkan sebagai juara 1 nagari berprestasi tingkat Provinsi Sumatera Barat. Dana tersebut digunakan oleh 5 orang perangkat nagari dan 1 orang ketua L PM Nagari untuk berlibur ke Jakarta. Dan juga belum terealisasinya dana dari anggota DPRD yang berjumlah RP.10 Juta pada tahun 2013 dan Rp.80 Juta pada tahun 2014 serta belum adanya peraturan nagari untuk Tim Pemeliharaan Program PNPM (TP3). Selain itu tidak adanya transparansi aset nagari, Dana Alokasi Umum Nagari (DAUN) serta reward yang diberikan oleh Provinsi Sumatera Barat kepada masyarakat. (wartaandalas.com: 2015).

Selain itu pada kenyataan di lapangan, pengelolaaan dana nagari juga dipengaruhi oleh beberapa faktor. Hal ini seperti faktor umur, dimana perangkat nagari yang sudah tidak muda terkadang kurang teliti dalam 
hal pengelolaan keuangan nagari. Penulis mendapat informasi dari beberapa informasi penelitian bahwa, banyak dari perangkat nagari tidak bisa mandiri dalam melaksanakan pekerjaan di kantor Walinagari Pasie Laweh, misalnya saja dalam penggunaan komputer, dikarenakan bebarapa hal seperti faktor umur.selain permasalahan pengelolan keuangan nagari juga terdapat permasalahan keterlambatan dana cair dalam pengelolaan keuangan nagari.

Selanjutnya berdasarkan penelitian terdahulu yang penulis temukan bahwa terdapat hasil penelitian yang menemukan bahwa Umur dan Status Perkawinan memiliki pengaruh terhadap kinerja, seperti penelitian yang dilakukan oleh R.A.Supriyono (2006), meneliti berbagai masalah yang berkaitan dengan kinerja yang mana salah satunya tentang partisipasi penganggaran terhadap kinerja manejer di Indonesia. Berdasarkan hasil penelitian ini pengaruh usia terhadap kinerja manajer di Indonesia. Dalam model teoritis, usia benar- benar mempengaruhi kinerja manajer dan ini memengaruhi lansung atau secara tidak langsung melalui tiga variabel intervening: keinginan sosial, kecukupan anggaran, dan partisipasi penganggaran. Selain itu Aprilyanti (2017) meneliti tentang Pengaruh Usia dan masa kerja terhadap produktifitas kerja (studi kasus: PT. Oasis Water Internasional Cabang Palembang), dari hasil penelitian didapat bahwa satu factor yang mempengaruhi produktifitas karyawan adalah factor usia atau umur. Usia dalam masa produktif biasanya memiliki tingkat produktifitas cendrung lebih tinggi daripada tenaga kerja yang telah berusia tidak muda lagi atau di sebut dengan tua yang memiliki fisik lebih lemah dan tak terbatas.

Berdasarkan uraian tersebut maka dapat disimpulkan bahwa masih terdapat hasil penelitian yang berbeda dengan variabel yang sama. Sehingga penulis tertarik untuk melakukan penelitian di Kabupaten Tanah
Datar dengan judul "Pengaruh Umur dan Status Perkawinan Terhadap Kinerja Perangkat Nagari Dalam Pengelolaan Keuangan Nagari di Kabuppaten Tanah Datar". Penelitian ini merupakan bagian dari penelitian payung yang dilakukan oleh Syamsir (2017) dengan judul Model Pembinaan Kapasitas Aparatur Pemerintahan Nagari dalam pengelolaan Keuangan Nagari di Kabupaten Tanah Datar.

\section{TINJAUAN PUSTAKA}

\section{Konsep Kinerja dan Faktor yang Mempengaruhi Kinerja}

Kinerja dapat dilihat dari dua segi, yaitu kinerja pagawai (individu) dan kinerja organisasi. Kinerja pegawai merupakan hasil kerja dalam organisasi. Sedangkan kinerja organisasi adalah suatu tindakan yang dilakukan secara terorganisir dan mempunyai peran sama dengan halnya kinerja pegawai yang mana memiliki ikatan satu sama lain. Terwujudnya tujuan dari organisasi belum bisa di lepaskan dari sumbernya organisasi yang digerakan atau yang di jalan oleh pegawai yang aktif sebagai pelaku untuk tercapainya tujuan dari organisasi itu sendiri (Pasolong, 2007). Prawirosentono (dalam Sinambela, 2017) menjelaskan kinerja merupakan suatu kesatuan orang dalam suatu organisai yang memiliki wewenang dan tanggung jawab dalam menjalankan tugas untuk mencapai suatu tujuan tertentu dalam suatu organisasi itu sendiri. Sementara menurut syamsir dan bayulis (2018) adalah kinerja mempunyai tiga komponen utama yaitu tujun, ukuran,dan penilian. Dimana penentuan tujuan dari setiap unit organisasi merupakan suatu bentuk strategi mengkatkan kinerja, dan tujuan dapat memberikan arah dan mempengaruhi prilaku atau sikap kinerja dari setiap prosonal terhadap apa yang diharapkan oleh organisasi. Sehingga kinerja merupakan suatu hasil yang diperoleh atau di capai orang seorang pegawai dalam menjalan tugasnya sesuai amanah yang diberikan kepadanya. 


\section{Faktor yang Mempengaruhi Kinerja}

Kinerja pegawai merupakan hasil gabungan dari beberapa faktor. Faktor tersebut dalam Wirawan (2009) yaitu sebagai berikut:

a) Faktor internal pegawai.

Merupakan faktor yang berasal dari sifat bawaan dari lahir pegawai serta faktor internal lainnya didapatkan ketika pegawai tersebut tumbuh dan berkembang, seperti kejiwaan, sifat sifat dasar pegawaidan keadaan fisik pegawai tersebut, sementara itu pengetahuan dan skill yang didapatkan pegawai merupakan faktor yang diperoleh ketika mereka telah berkembang.

b) Faktor -faktor lingkungan internal organisasi

Merupakan motivasi yang berasal dari organisasi kepada karyawan selama menjalankan pekerjaan, sehingga faktor ini dapat mempengaruhi kinerja dari pegawai, contohnya kelengkapan sumber daya atau sarana dan prasarana yang disediakan organisasi dalam menunjang pelaksanaan tugas, selain itu strategi dari organisasi tersebeut. Hal ini membuat lingkungan internal organisasi yang lebih kondusif dsn terkendali sehingga dapat meningkatkan kinerja dari pegawai.

c) Faktor lingkungan eksternal organisasi Yaitu faktor keadaan, kejadian atau situasi yang terjadi di lingkungan eksternal organisasi yang mempengaruhi karyawan.

d) Budaya masyarakat.

Ada beberapa faktor dari karakteristik individu menurut (Robbins 2006), antara lain:

\section{a) Umur}

Robbins (2006) menyatakan bahwa, semakin tua usia perangkat, maka makin tinggi komitmennya terhadap organisasi, hal ini disebebkan karena kesempatan individu untuk mendaptakan pekerjaan lain menjadi lebih terbatas sejalan dengan meningkatnya usia. Keterbatasan tersebut dipihak lain dapat meningkatkan persepsi yang lebih positif mengenai atasan sehingga dapat meningkatkan kinerja mereka terhadap organisasi.

Nitisemito (2000) menjelaskan bahwakaryawan atau perangkat yang lebih muda memiliki kondisi fisik yang sanggat, sehingga dapat bekerja dengan maksimal, namaun pegawai yang lebih muda ini pada umumnya memiliki masalah dengan kedisiplinan kerja dan masih kurang bertanggung jawab dengan pekerjaan jika dibandingkan dengan pegawai yang memiliki usia yang lebihlanjut.

Siagian (2002) bahwa terdapat hubungan antara kepuasan kerj dengan usia karyawan, hal ini disebabkan karena semakin tua karyawan maka kepuasan kerjanya pun semakin tinggi.

b) Status perkawinan

Menurut undang-undang perkawinan tahun 1974), status perkawinan merupakan ikatanlahir dan batin antara seseorang wanita dan laki laki yang telah membentik keluarga, dan telah mengikrarkan janji sesuai dengan kepercayaan masing masing. Status perkawinan menjadikan tanggung jawab terhadap pekerjaan menjadi lebih penting, sehingga karyawan yang telah menikah memiliki ketekunan terhadap pekerjaan dibandingkan dengan pegawai yang belum menikah, hal menjadikan status perkawinan berpengaruh terhadap peningkatkan dari kinerja pegawai. (Robbins 2006).

\section{Konsep Umur dan Status Perkawinan Berpengaruh terhadap Kinerja}

Umur atau usia adalah merupaka tolak ukur suatu benda atau mahkluk hidup dari masa ke masa. Kemungkinan besar hubungan antara umur dan kinerja merupakan isi yang makin penting selama dasa warsa yang akan datang. Ada keyakinan yang meluas bahwa kinerja merosot dengan meningkatnya usia. Robbins (1996), bahwa umur berkaitan erat dengan kedewasaan, semakin tinggi umur 
semakin mampu menunjukan kematangan jiwa dan semakin dapat berfikir rasional, semakin bijaksana, mampu mengendalikan emosi dan semakin terbuka terhadap pandangan orang lain, sehingga umur semakin matang akan lebih mampu memperlihatkan kinerja.

Menurut Hasibuan, (2003) umur individu mempengaruhi kondisi fisik, mental, kemampuan kerja. tanggung jawab, dan cenderung absensi. Sebaliknya, karyawan yang umurnya lebih tua kondisi fisiknya kurang, tetapi bekerja ulet, dan mempunyai tanggung jawab yang lebih besar.Umur juga berpengaruh terhadap produktivitas, di mana makin tua pekerja makin merosot produktivitasnya, karena ketrampilan, kecepatan, kecekatan, kekuatan dan koordinasi menurun dengan berjalannya waktu (Robbins, 2001). Penelitian yang dilakukan Riyadi \& Kusnanto (2007) bahwa faktor demografi yaitu umur dapat berpengaruh secara langsung serta memiliki hubungan positif terhadap kinerja.

Menurut Kartono (1992), perkawinan merupakan suatu institusi sosial yang diakui disetiap kebudayan atau masyarakat. Sekalipun makna perkawinan brbeda- beda, tetapi praktek-prakteknya perkawinan dihampiri semua kebudayaan cenderung sama perkawinan menunjukkan pada suatu peristiwa saat sepasang calon suami istri dipertemukan secara formal dihadapan ketua agama.

Menurut Yunus (dalam Asmin 1986), perkawina suatu ikatan janji suci antara laki laki dengan perempuan yang membentuk suatu kekeluargaan dan hidup bersama yang kekal, bahagia.(Ramulyo, SH dalam Asmin 1986).

Menurut Sarwono \& Soeroso (2001), status perkawinan juga diduga akan mempengaruhi emosional karyawan sehingga dapat berpengaruh emosional karyawan sehingga dapat berpengaruh terhadap situasi yang dihadapi di lingkungan kerja dan perilaku dalam bekerja.

\section{Pengelolaan Keuangan Nagari}

Menurut Undang Undang Nomor 6 tahun 2014 pasal 71 ayat 1 dan 2 disebutkan bahwa keuangan desa adalah semua hak dan kewajiban desa yang dapat dinilai dengan uang dan bentuk kegiatan yang dilakukan atas dasar uang dan memiliki hak dan kewajiban masing masing. Hak dan kewajiban tersebut akan menimbulkan pendapatan, belanja, pembiayaan, dan pengelolaan keuangan desa. Peraturan Daerah Sumatra Barat No. 9 Tahun 2000 tentang keuangan Nagari. Pada Pasal 1 ayat 12 di jelaskan bahwa Harta Kekayaan Nagari adalah harta benda yang telah ada atau yang kemudian menjadi milik dan kekayaan Nagari, baik bergerak maupun tidak bergerak. Selajutnya peraturan Bupati Tanah Datar Nomor 11 Tahun 2014 tentang pengelolaan Keuangan Nagari pasal 1 ayat 22 menyebutkan bahwa pejabat pengelolaan Keuangan Nagari yang selanjutnya di sebut PPK Nagari adalah Walinagari yang mempunyai tugas melaksanakan pengelolaan APBD Nagai dan bertindak sebagai Bendara Umum Nagari (BU Nagari).

Selanjutnya pengelolaan keuangan nagari adalah kegiatan yang dilakukan mulai awal atau dasar sebuah pengelolaan yang mana akan dilakukan atau dilaksanakan dari awal tahun dan akan berakhir hingga perhujung tahaun. Dalam pasal 1 ayat 13 tentang pengelolaan dana desa yaitu dimana pelaksanan teknis pengelolaan keuangan nagarai yang selanjutnya disingkat PTPKD adalah unsure perangkat desa yang membantu kepala desa untuk melaksanakan pengelolaan keuangan nagarau.

Permendagri Nomor 113 Tahun 2014 tentang pengelolaan keuangan desa Pasal 2 ayat 1 menyebutkan 'bahwa pengelolaan keuangan desa dilakukan transparan, akuntabel, partisipatif, tertib dan disiplin anggaran: 
a) Transparan, prinsip keterbukaan yang sangat membantu dalam menginformasikan kepada masyarakat tentang pengelolaan keuangan desa atau APBDesa.

b) Akuntabel, artinya proses seseolah yangtelah dipercaya juga di pertanggung jawabkan dalam pengelolaan dan pengendalina sumber daya yang te; ah di tentukan.

c) Partisipatif, artinya di dalam pengelolaan keuangan nagari masyarakat harus ikut serta dan berpatisipasi di dalam proses pengelolaan keuangan desa.

d) Tertib dan disiplin anggaran, yaitu mengaandung makna APBDesa. Di dalam pengelolaan keungan nagari harus dikelolah secara cepat dan tepat dalam waktu yang di tentukan sehingga dapat memberikan bukti administrasi yang bisa di pertanggung jawab kan dan berpedoman pada peraturan yang berlaku.

\section{METODE PENELITIAN}

Penelitian ini menggunakan metode kuantitatif yang merupakan analisisnya berupa data numerik atau angka yang diolah menggunakan metode statistik. Dalam penelitian ini peneliti membatasi populasi untuk dijadikan sampel yaitu hanya perangkat nagari yang terdiri dari 75 nagari di Kabupaten Tanah Datar. Sedangkan sampel penelitian ini berjumlah 248 responden yang ditentukan dengan rumus Slovin serta dilakukan dengan teknik pengambilan sampel Multi stage Random Sampling. Data yang digunakan dalam penelitian ini adalah data primer yakni data yang diperoleh secara langsung dari perangkat nagari yang menjadi responden, serta data sekunder yang di peroleh dari dokumen dokumen kantor wali nagari Kabupaten Tanah Datar. Teknik pengumpulan data menggunkan angket kuesoner dengan menyebarkan daftr pertanyaan yang di jadikan sampel penelitian.tekni analisis data menggunakan metode anallisis deskriptif, uju $\mathrm{t}$ dan uji anova.

\section{HASIL DAN PEMBAHASAN}

Hasil penelitian ini akan menjawab rumusan masalah yang terkait dalam pengaruh umur dan status perkawinan terhadap kinerja perangkat nagari dlam pengelolan keuangan nagari di kabupaten tanah datar? Untuk menjawab rumusan masalah mengenai faktor umur terhadap kinerja perangkat nagari dapat disajikan pada tabel 1, 2 dan 3 di bawah ini:

Tabel 1. Hasil Uji Anova Pengaruh Umur terhadap Kinerja Perangkat dalam Pengelolaan Keuangan Nagari.

ANOVA

rata-rata

\begin{tabular}{lccccc}
\hline & $\begin{array}{c}\text { Sum of } \\
\text { Squares }\end{array}$ & Df & Mean Square & F & Sig. \\
\hline Between Groups &, 337 & 4 &, 084 &, 697 &, 595 \\
Within Groups & 29,374 & 243 &, 121 & & \\
Total & 29,711 & 247 & & & \\
\hline
\end{tabular}

Sumber: data olahan SPSS 2019 
Wulan Sari Fadilla, Syamsirl Pengaruh Umur dan Status Perkawinan terhadap Kinerja Perangkat Nagari dalam Pengelolaan Keuangan Nagari di Kabupaten Tanah Datar

Tabel 2. Bonferroni

Multiple Comparisons

rata-rata

Bonferroni

\begin{tabular}{|c|c|c|c|c|c|c|}
\hline \multirow{2}{*}{$\begin{array}{l}\text { (I) } \\
\text { Umur }\end{array}$} & \multirow{2}{*}{$\begin{array}{l}(\mathrm{J}) \\
\text { Umur }\end{array}$} & \multirow{2}{*}{$\begin{array}{c}\text { Mean Difference } \\
(\mathrm{I}-\mathrm{J})\end{array}$} & \multirow[b]{2}{*}{ Std. Error } & \multirow[b]{2}{*}{ Sig. } & \multicolumn{2}{|c|}{$95 \%$ Confidence Interval } \\
\hline & & & & & Lower Bound & Upper Bound \\
\hline \multirow[t]{4}{*}{$20-30$} & $31-40$ & -.01185 & .05551 & 1.000 & -.1691 & .1454 \\
\hline & $41-50$ & .05176 & .06205 & 1.000 & -.1240 & .2276 \\
\hline & $51-60$ & -.06920 & .07395 & 1.000 & -.2787 & .1403 \\
\hline & $61-70$ & .07117 & .13725 & 1.000 & -.3177 & .4600 \\
\hline \multirow[t]{4}{*}{$31-40$} & $20-30$ & .01185 & .05551 & 1.000 & -.1454 & .1691 \\
\hline & $41-50$ & .06361 & .06158 & 1.000 & -.1108 & .2381 \\
\hline & $51-60$ & -.05735 & .07356 & 1.000 & -.2657 & .1510 \\
\hline & $61-70$ & .08302 & .13704 & 1.000 & -.3052 & .4712 \\
\hline \multirow[t]{4}{*}{$41-50$} & $20-30$ & -.05176 & .06205 & 1.000 & -.2276 & .1240 \\
\hline & $31-40$ & -.06361 & .06158 & 1.000 & -.2381 & .1108 \\
\hline & $51-60$ & -.12096 & .07861 & 1.000 & -.3437 & .1017 \\
\hline & $61-70$ & .01941 & .13982 & 1.000 & -.3767 & .4155 \\
\hline \multirow[t]{4}{*}{$51-60$} & $20-30$ & .06920 & .07395 & 1.000 & -.1403 & .2787 \\
\hline & $31-40$ & .05735 & .07356 & 1.000 & -.1510 & .2657 \\
\hline & $41-50$ & .12096 & .07861 & 1.000 & -.1017 & .3437 \\
\hline & $61-70$ & .14037 & .14549 & 1.000 & -.2718 & .5525 \\
\hline \multirow[t]{4}{*}{$61-70$} & $20-30$ & -.07117 & .13725 & 1.000 & -.4600 & .3177 \\
\hline & $31-40$ & -.08302 & .13704 & 1.000 & -.4712 & .3052 \\
\hline & $41-50$ & -.01941 & .13982 & 1.000 & -.4155 & .3767 \\
\hline & $51-60$ & -.14037 & .14549 & 1.000 & -.5525 & .2718 \\
\hline
\end{tabular}

Sumber: data olahan SPSS 2019

Tabel 3. Rata Rata Pengelolaan Keuangan Nagari

Rata Rata Pengelolaan Keuangan Nagari

\section{Descriptives}

\begin{tabular}{|c|c|c|c|c|c|c|c|c|}
\hline & \multirow[b]{3}{*}{$\mathbf{N}$} & \multirow[b]{3}{*}{ Mean } & \multirow{3}{*}{$\begin{array}{c}\text { Std. } \\
\text { Deviat } \\
\text { ion }\end{array}$} & \multirow[b]{3}{*}{$\begin{array}{l}\text { Std. } \\
\text { Error }\end{array}$} & \multirow{2}{*}{\multicolumn{2}{|c|}{$\begin{array}{l}\text { 95\% Confidence } \\
\text { Interval for Mean }\end{array}$}} & \multirow[b]{3}{*}{ Minimum } & \multirow[b]{3}{*}{ Maximum } \\
\hline & & & & & & & & \\
\hline & & & & & $\begin{array}{l}\text { Lower } \\
\text { Bound }\end{array}$ & $\begin{array}{l}\text { Upper } \\
\text { Bound }\end{array}$ & & \\
\hline 20-30 tahun & 77 & 3.2640 & .35019 & .03991 & 3.1845 & 3.3435 & 2.67 & 4.00 \\
\hline 31-40 tahun & 80 & 3.2759 & .32383 & .03621 & 3.2038 & 3.3479 & 2.67 & 4.00 \\
\hline $41-50$ tahun & 53 & 3.2123 & .36185 & .04970 & 3.1125 & 3.3120 & 2.13 & 4.00 \\
\hline 51-60 tahun & 31 & 3.3332 & .39349 & .07067 & 3.1889 & 3.4776 & 2.80 & 4.00 \\
\hline 61-70 tahun & 7 & 3.1929 & .22954 & .08676 & 2.9806 & 3.4051 & 2.87 & 3.47 \\
\hline Total & 248 & 3.2634 & .34683 & .02202 & 3.2200 & 3.3068 & 2.13 & 4.00 \\
\hline
\end{tabular}

Berdasarkan tabel 1 dapat dilihat bahwa

keseluruhan dengan hasil yang tidak pengaruh umur terhadap kinerja secara signifikan yaitu 0,595 , lebih besar dari 0.005. berdasarkan tabel 2 mengenai 
Wulan Sari Fadilla, Syamsirl Pengaruh Umur dan Status Perkawinan terhadap Kinerja Perangkat Nagari dalam Pengelolaan Keuangan Nagari di Kabupaten Tanah Datar

pengelolaan keuangan nagari perangkat nagari berdasarkan umur secara sendiri sendiri, menunjukkan tidak ada yang signifikan. Umur 20-30 tahun angka signifikan 1,0. Sedangkan umur 31-40 tahun angka signifikan 1,0. Kemudian umur 41-50 tahun angka signifikan 1,0. Sementara itu umur 51-60 tahun angka signifikan 1,0. Selanjutnya umur 61-70 tahun angka signifikan 1.0. kemudian tabel 3 Rata rata pengelolaan keuangan nagari dengan umur 20-30 tahun menunjukan angka3.2640. Sedangkan umur 31-40 tahun menunjukan angka 3.2759. Kemudian umur
41-50 tahun menunjukan angka 3.2123. Sementara itu umur 51-60 menunjukan angka 3.3332. Selanjutnya umur 61-70 menunjukan angka 3.1929. Dari ratarata umur dapat dilihat bahwa pengelolaan yang paling tinggi adalah umur 51-60tahun. Sedangkan yang paling rendah adalah umur 61-70tahun.

Selanjutnya untuk melihat pengaruh status perkawinan terhadap kinerja pengelolaan keuangan nagari dapat dilihat analisis yang terdapat pada tabel 4 dan 5 berikut:

\section{Tabel 4. Pengaruh Status Perkawinan Terhadap Kinerja Perangkat dalam Pengelolaan Keuangan Nagari. \\ Independent Sample T-Test}

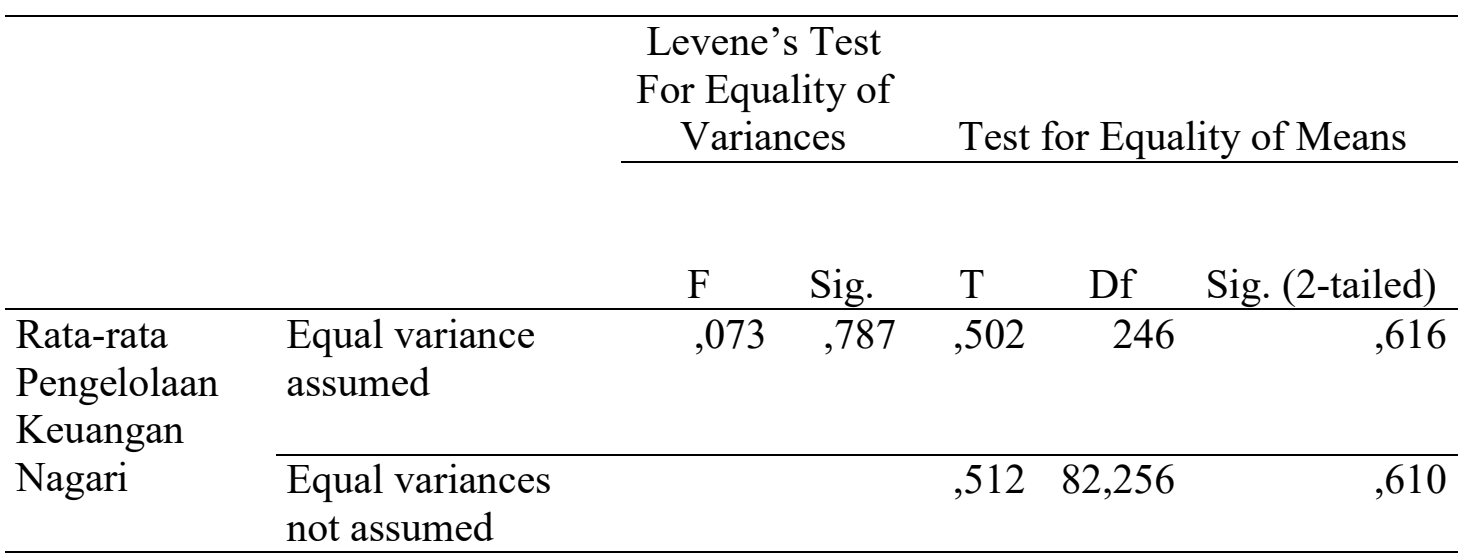

Sumber: data olahan SPSS 2019

Tabel 5. Group Statistic

Group Statistics

\begin{tabular}{|c|c|c|c|c|c|}
\hline & $\begin{array}{l}\text { Status } \\
\text { Perkawinan }\end{array}$ & $\mathrm{N}$ & Mean & Std. Deviation & Std. Error Mean \\
\hline \multirow[t]{2}{*}{ rata-rata } & Kawin & 196 & 3.2691 & .34965 & .02498 \\
\hline & Belum kawin & 52 & 3.2419 & .33840 & .04693 \\
\hline
\end{tabular}

Sumber: data olahan SPSS 2019

Berdasarkan tabel dapat dilihat angka nilai yang berbeda beda. Rata rata signifikan pada Uji F memiliki angka 0,787 lebih besar dari 0.05. Karena hasil Uji F adalah tidak signifikan, maka digunakan angka signifikansi Uji $\mathrm{T}$ pada baris Equal variences assumed. Hasil uji $\mathrm{T}$ tersebut menunjukkan angka 0,610. Angka ini lebih besar dari 0,05. Akan tetapi pada tabel 5, berdasarkan status perkawinan memiliki pengelolaan keuangan nagari dengan orang yang memiliki status kawin menunjukan angka3.2691 sedangkan yang belum kawin memiliki rata rata 3.2419. Dengan selisis sebesar 0,0272. Akan tetapi perbedaannya tidak begitu berarti.

Hasil penelitian tentang pengaruh umur dan status perkawinan terhadap kinerja 
perangkat nagari dalam pengelolaan keuangna nagari untuk variabel umur tidak berpengaruh signifikan terhadap pengelolaan keuangan dengan angka signifikan 0,595. Akan tetapi jika dilihat secara satu persatu masing masing umur kinerja memiliki tingkat yang berbeda beda. Umur kinerja yang paling tinggi adalah umur 51-60tahun dan kemudian yang paling rendah adalah 61-70tahun.

Selain itu teori yang membahas mengenai pengaruh umur terhadap kinerja. Hasil penelitian ini tidak sejalan dengan beberapa teori yang menyatakan bahwa umur akan menentukan bagaimana seseorang dalam melakukan pekerjaannya. Salah satunya menurut Robbins (1996), bahwa umur berkaitan erat dengan kedewasaan, semakin tinggi umur semakin mampu menunjukan kematangan jiwa dan semakin dapat berfikir rasional, semakin bijaksana, mampu mengendalikan emosi dan semakin terbuka terhadap pandangan orang lain, sehingga umur semakin matang akan lebih mampu memperlihatkan kinerja. Kemudian teori selanjutnya menurut Depkes RI (2009) Usia kronologis adalah perhitungan usia yang dimulai dari saat kelahiran sesorang samapai waktu perhitungan usia. Usia mental adalah perhitungan usia yang didapatkan dari taraf kemampuan mental seseorang.

Selain itu penelitian ini juga berbeda dengan hasil penelitian yang dilakukan oleh beberapa peneliti yang menyatakan bahwa umur berpengaruhi terhadap kinerja, seperti penelitian yang dilakukan oleh (Hasibuan, 2003) bahwa umur individu mempengaruhi kondisi fisik, mental, kemampuan kerja ,tanggung jawab, dan cenderung absensi. Sebaliknya, karyawan yang umurnya lebih tua kondisi fisiknya kurang, tetapi bekerja ulet, dan mempunyai tanggung jawab yang lebih besar. Begitupun menurut (Robbins, 2001). Umur berpengaruh pada kinerja perangkat Nagari dalam menjalankan tugas, pada saat ini umur juga di dahulukan dalam penerimaan perangkat Nagari, yaitu umur seorang pelamar kerja atau seorang pegawai perangkat Nagari harus minimal berumur 20 tahun dan maksimal umur 60 tahun dan semua harus melaksanakan pendidikan terlebih dahulu.

Kemudian untuk pengaruh status perkawinan terhadap kinerja perangkat nagari dalam pengelolaan keuangan nagari untuk variabel status perkawinan bahwa tidak terdapat perbedaan orang yang kawin dengan orang yang belum kawin dalam pengelolaan keuangan nagari. Akan tetapi kinerja pengelolaan keuangan antara kawin dan belum kawin memiliki selisih. Secara bersama sama perbedaan pengelolaan antara kawin dengan belum kawin memiliki selisih 0,03. Dimana pengelolaan keuangan yang sudah kawin lebih baik dari yang belum kawin. Terdapat perbedaan antara pengelolaan keuangan yang sudah kawin dengan yang belum kawin namun tidak signifikan terhadap kinerja pengelolaan keuangan nagari di Kabupaten Tanah Datar.

Selain itu penelitian mengenai status perkawinan juga berbeda dengan hasil penelitian yang dilakukan oleh beberapa peneliti Berdasarkan penelitian Azim et al., (2013); Miyoung et al., (2016) dan Al Ahmadi, (2009) status perkawinan berpengaruh bagi kinerja. Karena sekarang lebih banyak perempuan yang bekerja dari pada laki laki. Peran ideal perempuan itu lebih baik di rumah dari pada bekerja di luar rumah. Sedangkan peran laki laki bekerja di luar rumah karena laki laki itu adalah seorang kepala keluarga yang harus mencari nafka . Status perkawinan sangat berpengaruh bagi perangkat nagari karena pegawai yang sudah memiliki status perkawinan lebih sering meluangkang waktunya di rumah bersama keluarganya, dan itu perpengaruh bagi kinerja perangkat nagari.

Pria dan wanita yang telah menikah cendrung memiliki masa untuk bekerja yang lebih panjang dibanding dengan pria dan wanita yang belum menikah. Wanita yang telah menikah khususnya, memiliki 
masa untuk bekerja yang lebih panjang di banding dengan pria yang telah menikah (CUSBOS.2007).Berdasarkan teori mengenai perkawinan diatas, dapat simpulkan bahwa perkawinan berarti suatu perjanjian suci antara seorang laki-laki dan perempuan dalam bentuk keluarga. Merujuk pada pengertian tersebut, maka status perkawinan dalam hal ini adalah keadaan dan kedudukan perkawinan yang telah berlangsung.

Hasil penelitian tidak sejalan dengan beberapa penelitian mengenai pengaruh umur terhadap kinerja. Hasil penelitian ini tidak sejalan dengan penelitian menyatakan bahwa umur akan menentukan bagaimana seseorang dalam melakukan pekerjaannya. Salah satunya penelitian yang dilakukan oleh Aprilyanti (2017) faktor usia, usia yang masih dalam masa produktif biasanya mempunyai tingkat produktifitas lebih tinggi dibandingkan dengan tenaga kerja yang sudah berusia tua sehingga fisik yang dimiliki menjadi lemah dan terbatas.

Dari penjelasan di atas dapat di ambil kesimpulan bahwa status perkawinan tidak berpengaruh secara signifikan terhadap kinerja perangkat nagari dalam pengelolaan keuangan nagari di Kabupaten Tanah Datar. Akan tetapi hasil penelitian ini tidak sejalan dengan penelitian yang dilakukan oleh Nur Afni Ambarwati (2014), dari hasil penelitian di dapat hasil bahwa variabel status perkawinan berpengaruh secara signifikan terhadap kinerja.

\section{PENUTUP}

Berdasarkan hasil temuan dan pembahasan yang telah diuraikan sebelumnya, dapat disimpulkan bahwa :

1) Pengaruh umur perangkat terhadap pengelolaan keuangan nagari memiliki nilai signifikansi sebesar 0,595lebih besar dari 0,05. Karena memiliki nilai signifikansi lebih besar dari 0,05 maka $\mathrm{H}_{\mathrm{o}}$ diterima dan $\mathrm{H}_{\mathrm{a}}$ ditolak. Hal ini berarti tidak ada pengaruh secara signifikan umur terhadap kinerja pengelolaan keuangan nagari.
2) Pengaruh status perkawinan terhadap pengelolaan keuangan nagari memiliki nilai signifikansi sebesar 0,787 lebih besar dari 0,05. Karena memiliki nilai signifikansi lebih besar dari 0,05 maka $\mathrm{Ho}_{\mathrm{O}}$ diterima dan $\mathrm{H}_{\mathrm{a}}$ ditolak. Hal ini berarti juga tidak ada pengaruh secara signifikan status perkawinan terhadap kinerja pengelolaan keuangan nagari.

Berlatarbelakang dari hasil penelitian dan kesimpulan yang telah diuraikan di atas, maka penulis memberikan saran saran, diantaranya:

1) Hasil penelitian ini menunjukkan bahwa variabel umur dan status perkaiwnan memberikan pengaruh yang tidak signifikan bagi perangkat dalam pengelolaan keuangan nagari di Kabupaten Tanah Datar. Akan tetapi jika dilihat secara sendiri sendiri umur perangkat nagariDari rata rata umur dapat dilihat bahwa pengelolaan yang paling tinggi adalah umur 51-60tahun. Sedangkan yang paling rendah adalah umur 61-70tahun. Kemudian untuk variabels status perkawinan, pengelolaan keuangan perangkat rata rata status perkawinan terhadap pengelolaan keuangan nagari berdasar table dapat di lihat bahwa yang berstatus kawin memiliki angka tertinggi dariperangkat yang berstatus belum kawin dan janda atau duda.

2) Penelitian yang dilakukan masih terdapat berbagai kelemahan dan kekurangan, diharapkan pada peneliti berikutnya untuk lebih mendalam dalam melakukan penelitian ini dengan melibatkan berbagai variabel lain yang mungkin juga dapat berpengaruh terhadap aparatur dalam pengelolaan keuangan nagari di Kabupaten Tanah Datar.

\section{DAFTAR KEPUSTAKAAN}

Ambarwati Afni Nur, dkk. 2014. "Analisis Pengaruh Kecerdasan Emosional, Pelatihan, Intervensi Keluarga, Dan 
Wulan Sari Fadilla, Syamsirl Pengaruh Umur dan Status Perkawinan terhadap Kinerja Perangkat Nagari dalam Pengelolaan Keuangan Nagari di Kabupaten Tanah Datar

Status Perkawinan Terhadap Kinerja Keryawan Pada Rsud Kelet'.

Apriyanti Selvia. 2017. 'Pengaruh Usia dan Masa Kerja Terhadap Produktivitas Kerja ( studi Kasus : PT. OASIS Water Internasional Cabang Palembang)". Jurnal Sistem Manajemen Industri Vol. 1,No,2, Desember 2017.

Asmin. 1986. Status Perkawinan Antara Agama, Jakarta : PT. Dian Rakyat.

BPK. 2014. Badan Pemerikasaan Keuangan, Hasil Pemeriksaan Keuangan Semester 1. http://www.bpk.go.id/news/hasilpemeriksaan-bpk-semester-i-tahun2004. Diakses pada 13 februari 2018.

Hadi, Sopian. 2015. Alokasi Dana Desa Dan Tantangannya. http://www.Kompasiana.com/Sopianh adi83/54f6837da33311e6058b4e9f/alo kasi-dana-desa-dan-tantangan.

Hasibuan, M.S.P.2003. Manajemen Sumber Daya Manusia Teori dan Aplikasi. Bandung:Bumi Aksara.

Media Harapan. 2015. Baru Tugas di Sumbar, Kajati Langsung Kungker Ke Tanah Datar. http://mediaharapan.com.baru-tugasdi-sumbar-kejati-langsung-kungkerke-tanah-datar. Diakses tanggal28 Septemeber 2018.

Murtino, Yusuf. 2016. Tata Kelola Keuangan Desa. Yogyakarta: Infest.

Nitisemito, 2000. Manajemen Sumber Daya Manusia, Ed. 3. Ghalia Indonesia, Jakarta.

Pasolong, Harbani. 2007. Teori Administrasi Publik. Bandung: Alfabeta.

Peraturan Bupati Tanah Datar Nomor 7 Tahun 2016 Tentang Perubahan Atas
Paraturan Bupati Tanah Datar Nomor 11 Tahun 2015 Tentang Pedoman Pengelolaan Keuangan Nagari.

Peraturan Daerah Kabupaten Tanah Datar Nomor 4 Tahun 2008 Tentang Nagari.

Peraturan Mentri Dalam Negeri Nomor 113 Tahun 2014 Tentang Pedoman Pengelolaan Keuangan Nagari.

Peraturan Mentri Dalam Negeri Nomor 114 Tahun 2014 Tentang Pedoman Pembangunan Desa.

Redaksisumbar.com. 2017. Tiga Nagari Bermasalah, Pemkab Tanah Datar Terancam Tidak Dapat Cairkan Dana ADD Tahap II. http://redaksisumbar.com./akibat-tiganagari-bermasalah-pemkab-tanahdatar-terancam-tidak-dapat-cairkandana-add-tahap-ii. Diakses tanggal 20 Mei2018.

Robbins, Stephen P.1996, Perilaku Organisasi, Konsep, Kontoversi dan Aplikasi, ( terjemhan edisi kedelapan) PT Prenhallindo, Jakarta.

Robbins, Stephen P.1996. Perilaku Organisasi Edisi ke 7 (jilid II). Jakarta: Prehallindo.

Robbins, Stephen P.2006. Perilaku Organisasi, PT Indeks, Kelompok Gramedia, Jakarta.

Sarwono, S.S. \& Soeroso, A. 2001. Determinasi Demografi terhadap Perilaku Kuratif Keorganisasian. Jurnal Siasat Bisnis. ISSN. 0853-7665, Vol. 1, No. 6.

Siagian, S. P. 2002. Kiat Meningkatkan Produktivitas Kerja. Jakarta: Rineka cipta

Sinambel, Lijan Poltak.2017, Manajemen Sumber Daya Manusia. Jakarta : PT Bumi Aksara. 
Sugiono. 2009. Metode Penelitian

Pendidikan, Kualitatif dan $R \& D$.

Bandung: Alfabeta.

Sugiono. 2013. Metode Penelitian Administrasi dilengkapi dengan Metode R\&D. Bandung: Alfabeta.

Sugiono. 2016. Metode Penelitian Administrasi dilengkapi dengan Metode $R \& D$. Bandung: Alfabeta.

Sunar. 2012. 'Pengaruh Faktor Biografis (Usia, Masa Kerja, Dan Gender) Terhadap Produktivitas Karyawan (Studi Kasus PT Bank X '. Forum Ilmiah Volume 9 November 1, Mei 2012.

Supriono Ra. 2006. 'Pengaruh Usia, Keinginan Sosial, Kecukupan Anggaran, Dan Partisipasi Penggagaran Terhadap Kinerja Manejer di Indonesia.

Syamsir. 2017. 'Model Pembinaan Kapasitas Aparatur Pemerintahan Nagari Dalam Pengelolaan Keuangan Nagari di Kabupaten Tanah Datar. Laporan penelitian, Padang: UNP.

Undang Undang Nomor 6 Tahun 2014 Tentang Desa.

Wibowo. 2016. Manajement Kinerja. Jakarta : PT. Raja Grafindo Persada. 